\title{
GAMBARAN SEDENTARY LIFESTYLE, AKTIFITAS FISIK, DAN KELUHAN PADA TUBUH KARYAWAN USIA PRODUKTIF DI KANTOR BALAI KOTA PADANG 2021
}

\author{
Noly Papertu Englardi ${ }^{1)}$, Cindy Cleodora ${ }^{2)}$ \\ ${ }^{1,2}$ Sekolah Tinggi Ilmu Kesehatan Indonesia \\ e-mail : papertu09.englardi@gmail.com
}

\begin{abstract}
ABSTRAK
Karyawan memiliki risiko kesehatan saat mereka bekerja. Salah satu yang mempengaruhinya ialah perilaku dan gaya hidup. Hasil penelitian tentang Sedentary Lifestyle sebagai faktor permasalah kesehatan usia produktif didapatkan $86 \%$ berperilaku kurang gerak. Perilaku karyawan kantor biasanya menghabiskan waktu 6 jam perhari dibalik meja kerja, serta menghabiskan waktu istirahat mereka untuk mengobrol, main game, menonton dan bermain sosial media, sehingga karyawan kurang aktivitas gerak dan cendrung berdiam diri di tempat. Kesehatan karyawan merupakan unsur terpenting dalam mencapai produktifitas kerja, namun rendahnya kesadaran dalam menjaga kesehatan dan kebugaran tubuh dapat menyebabkan masalah kesehatan terutama penyakit tidak menular. Perawat mempunyai peranan penting dalam meningkatkan kesehatan kerja melalui edukasi, promosi serta pencegahan terjadinya masalah kesehatan pada karyawan, akan tetapi peranan perawat pada saat ini masih belum mempunyai ruang untuk melakukan intervensi langsung di perkantoran. Tujuan penelitian ini melihat gambaran Sedentary Lifestyle, aktifitas fisik, dan keluhan tubuh pada karyawan usia produktif. Jenis penelitian ini adalah deskriptif analitik dengan sampel sebanyak 71 karyawan. Pengolahan data menggunakan metode analitik dengan Global Physical Activity Quesioner hasil, hasil yang didapatkan 56,5 karyawan memiliki aktifitas fisik ringan. Pengukuran sedentary lifestyle didapatkan hasil $93 \%$ karyawan memiliki perilaku sedentary lifestyle yang tinggi, dan pengukuran keluhan tubuh dengan Nordic Body Map didapatkan hasil 91,5\% karyawan mengalami kesakitan tubuh yang rendah. Perawat dan pemangku kebijakan perlu melakukan kegiatan Total Body Stretch secara teratur untuk meningkatkan kualitas kesehatan dan produktifitas karyawan kantor. Kegiatan ini diharapkan mengurangi dampak dari Sedentary Lifestyle yang cukup tinggi pada karyawan.
\end{abstract}

Kata Kunci: aktivitas fisik; nordic body map; promosi kesehatan; sedentary lifestyle; total body stretch

\begin{abstract}
Employees have health risks while they work. One of the factors that influence it is behavior and lifestyle. The results of research on Sedentary Lifestyle as a factor in health problems of productive age found 86\% of behaving sedentary. The behavior of office employees usually spends 6 hours per day behind their desks, and spends their rest time chatting, playing games, watching and playing social media, so that employees are less active and tend to stay in place. Employee health is the most important element in achieving work productivity, but low awareness in maintaining health and body fitness can cause health problems, especially non-communicable diseases. Nurses have an important role in improving occupational health through education, promotion and prevention of health problems in employees, but the role of nurses at this time still does not have the space to intervene directly in the office. The purpose of this study is to look at the description of the Sedentary Lifestyle, physical activity, and body complaints in employees of productive age. This type of research is descriptive analytic with a sample of 71 employees. Data processing using analytical methods with Global Physical Activity Questionnaire results, the results obtained are 56.5 employees have light physical activity. Measurement of
\end{abstract}


sedentary lifestyle showed that 93\% of employees had high sedentary lifestyle behavior, and measurement of body complaints with the Nordic Body Map showed that $91.5 \%$ of employees experienced low body pain. Nurses and policy makers need to carry out Total Body Stretch activities regularly to improve the health quality and productivity of office employees. This activity is expected to reduce the impact of the Sedentary Lifestyle which is quite high on employees.

Keyword: health promotion; nordic body map; physical activity; sedentary lifestyle; total body stretch.

\section{PENDAHULUAN}

Kesehatan kerja adalah jaminan kesehatan pada saat melakukan pekerjaan yang bertujuan untuk meningkatkan dan memelihara derajat kesehatan baik secara fisik, mental, sosial, yang setinggitingginya bagi semua pekerja disemua sektor pekerjaan. Dalam aktfitas bekerja populasi dewasa memiliki masalah terkait kesehatan seperti, stress kerja, kelelahan, kesalahan dalam bekerja, depresi, mengkonsumsi rokok dan alkohol sebagai perubahan sosial yang negatif di lingkungan kerja (Anderson and McFarlane, 2011).

Populasi pekerja merupakan salah satu populasi yang berisiko (at risk population) berkaitan dengan hazard atau bahaya yang ada di tempat kerja (Anderson, 2018). Setiap pekerja memiliki risiko kesehatan pada saat mereka bekerja. Karakteristik risiko bahaya kesehatan kerja pada pekerja yaitu, biologi, gaya hidup dan lingkungan. Risiko biologis pada pekerja yaitu seperti usia dan jenis kelamin. Karateristik risiko berikutnya yaitu gaya hidup atau perilaku pekerja pada saat bekerja (Guzik, 2013).

Perilaku pekerja atau karyawan yang kurang baik akan menimbulkan permasalahan pada pekerja tersebut terutama kesehatan, salah satu permasalah kesehatan yang dapat ditimbulkan oleh perilaku karyawan terutama pada pekerja kantor yaitu sedentary lifestyle atau perilaku kurang gerak biasa disebut mager (malas gerak). Para pekerja kantor rata-rata menghabiskan waktu bekerja sambil duduk lebih dari 6 jam dalam sehari, mulai dari dikendaraan saat berangkat dan pulang kerja, saat bekerja, istirahat, nongkrong, dll. Selain itu tidak adanya objek untuk mengalihkan kebiasaan duduk saat bekerja, membuat pekerja tetap melakukan duduk saat beristirahat sebentar dengan bermain smarthphone ataupun menonton youtube (Amalina, 2020a)

Perkembangan teknologi dapat mengubah gaya hidup dan pola hidup masyarakat karena membuat segala sesuatu menjadi instan. Kemajuan teknologi juga mendorong orang memiliki gaya hidup sedentary. Gaya hidup sedentary bisa disebut juga malas gerak (mager), gaya hidup sedentary adalah salah satu jenis gaya hidup dimana seseorang kurang melakukan gerak atau kurang melakukan aktivitas fisik yang berarti (Amalina, 2020b).

Upaya kesehatan kerja merupakan amanat UU RI No.36 tahun 2009 tentang kesehatan kerja pasal 165 mnyebutkan bahwa upaya kesehatan kerja di tunjukan untuk pekerja agar hidup sehat dan terbebas dari pengaruh pekerjaan (arsip indonesia: undang-undang republik indonesia nomor 36 tahun 2009 tentang kesehatan, no date). Keperawatan kesehatan kerja atau yang disebut Occupational Health Nursing (OHN) merupakan cabang khusus dari keperawatan komunitas (Anderson and McFarlane, 2011).

Perawat kesehatan kerja memiliki peran penting dalam meningkatkan status kesehatan pekerja supaya tercapai manfaat untuk institusi yang menggunakan jasa pekerja. Peran tersebut dilakukan dalam upaya memberikan perlindungan, pencegahan dan promosi kesehatan pada pekerja (Oakley, 2008). Perawat kesehatan kerja mempunyai peran dalam upaya melakukan pencegahan terhadap 
kesehatan karyawan di tempat kerja (Oakley, 2008). Salah satu upaya pencegahan mengatasi sedentary lifestyle guna mengurangi risiko kesehatan pada karyawan yaitu melakukan kampanye dan penerapan berolah raga ringan dengan cara melakukan total body stretch disela-sela kerja (Halajur, 2019).

Data yang dirilis oleh WHO pada tahun 2015, pekerja yang memiliki gaya hidup kurang gerak atau pekerja yang terlalu lama duduk pada saat bekerja memilik peringkat ke 4 penyebab kematian di dunia. Pada tahun 2016 angka kematian dengan kebiasaan duduk terus meningkat. Sebuah studi yang diterbitkan oleh American Journal of preventive Medicine menemukan bahwa pekerja yang duduk lebih dari 3 jam/hari meningkatkan 3,8\% risiko kematian dini. Dr James Levine, seorang dokter Mayo Clinic di Rochester menyebutkan bahwa duduk terlalu lama dapat menimbukan penyakit yang sama sepertu efek samping merokok. Ia juga menyebutkan bahwa pekerja dewasa yang duduk lebih dari 4 jam/hari memiliki $80 \%$ risiko kematian akibat penyakit jantung, dibandingkan orang yang duduk kurang dari 2 jam/hari. Ia juga menambahkan jika hanya dengan berdiri, tubuh membakar lebih banyak kalori dari pada duduk (Thyfault et al., 2015).

Tujuan dari penelitian ini ialah melihat gambaran sedentary lifestyle, aktifitas fisik, dan keluhan tubuh pada karyawan usia produktif di kantor balai kota Padang 2021.

Upaya yang telah dilakukan guna membantu program pemerintah kota dalam peningkatan produktifitas dan kesehatan kerja perlu diadakan kampanye kesehatan dalam gerak aktif dan stretching pada saat bekerja dikalangan karyawan balai kota.

\section{METODE PENELITIAN}

Jenis penelitian ini merupakan penelitian kuantitatif dengan design deskriptif analitik studi. Penelitian ini dilaksanakan pada bulan MaretNovember 2021 di kantor Balai Kota Padang. Populasi pada penelitian ini adalah seluruh karyawan Balai Kota Padang yang dengan usia produktif yaitu sebanyak 97 orang. Pemilihan sampel pada penelitian ini menggunakan total sampel dimana didapatkan sampel sebanyak 71 orang sesuai dengan kriteria inklusi dan ekslusi.

Proses penelitian ini menggunakan Teknik pengumpulan data dengan cara menyebarkan kuesioner baku sesuai dengan variabel yang dibutuhkan yaitu, Sedentary Quesioner. (WHO, 2012) Global Physical Activity Quesioner, (WHO, 2012) dan Nordic Body map. (Wijaya, 2019) dan dilakukan pengolahan data dengan langkahlangkah, editing, coding, entry dan cleaning. Analisa data pada penelitian ini menggunakan analisa univariat untuk melihat gambaran distribusi frekuensi di setiap variable yaitu, sendentary lifestyle, physical activity, dan nordic body map.

\section{HASIL DAN PEMBAHASAN}

a. Gambaran Sedentary Lifestyle pada karyawan usia produktif di Balai Kota Padang

Tabel 4.1 distribusi frekuensi responden yang mempunyai kebiasaan sedentary lifestyle pada karyawan usia produktif di Balai Kota Padang.

\begin{tabular}{ccc}
\hline $\begin{array}{c}\text { Sedentary } \\
\text { Lifestyle }\end{array}$ & Frequensi & $\%$ \\
\hline Rendah & 5 & 7 \\
\hline Tinggi & 66 & 93 \\
\hline Total & 71 & 100 \\
\hline
\end{tabular}

Hasil penelitian didapatkan sebanyak 93\% karyawan usia produktif memiliki perilaku kurang gerak yang tinggi. Ratarata waktu kurang gerak yang didapatkan pada karyawan Balai kota Padang adalah $10 \mathrm{jam} / \mathrm{hari}$.

Penelitian (Mandriyarini, 2016) dengan judul Sedentary Life style sebagai faktor permasalah kesehatan pada usia produktif didapatkan $86 \%$ usia produktif berperilaku kurang gerak, hal tersebut juga dinarasikan, semakin bertambah usia maka semakin tinggi tingkat perilaku kurang gerak. Perubahan status sosial, gaya hidup serta kemajuan sebagai bentuk kemudahan menghasilkan pola hidup santai pada masyarakat terutama 
diusia produktif. Beberapa studi mengenai sedentary lifestyle dari pekerja kantoran atau yang sering disebut sebagai pekerja kantoran kerah putih menemukan hasil serupa. menyebutkan bahwa pekerja kantoran memiliki kecendrungan untuk berdiam diri disuatu tempat atau di meja kerja. Cukup banyaknya waktu yang dihabiskan di kantor (kurang lebih $8 \mathrm{jam} / \mathrm{hari}$ ) dan aktivitas yang cenderung sedentary diduga menjadi penyebab kurang aktifnya para pekerja kantoran .

Sedentary lifestyle merupakan salah satu dari kegiatan aktifitas fisik ringan. Batasanya adalah rata-rata aktivitas fisik yang dilakukan kurang dan sangat rendah untuk melakukan aktifitas fisik Abadani \& Wuryaningsih, (2018). Sedentary lifestyle adalah gaya hidup duduk atau berbaring dalam sehari-hari baik di tempat kerja seperti di meja kantor, didepan computer, membaca, dll. Di rumah seperti menonton $\mathrm{TV}$, main game, di perjalanan/transportasi seperti diatas motor, bus, kereta dll. Tetapi tidak termasuk waktu tidur.

Asumsi peneliti melihat tinggi nya angka sedentary life style pada karyawan usia produktif di Balai Kota Padang. Faktor terjadinya perilaku sedentary lifestyle pada karyawan kantor Balai Kota Padang salah satunya adalah lingkungan dan jenis pekerjaan yang menuntut pekerja untuk banyak duduk dan bekerja dibalik meja, serta kurangnya pengetahuan tentang prilaku sedentary lifestyle tersebut. Dilihat dari perilaku pekerja yang banyak melakukan duduk dikantor dan di ruang terbuka lainya seperti bermain handphone/gam, menonton youtube dan mengobrol di waktu istirahat. Hal tersebut bisa berdampak terhadap fisik dan kesehatan pekerja akibat sedentary lifestyle.

\section{b. Gambaran aktivitas fisik pada pada karyawan usia produktif di Balai Kota Padang}

Tabel 4.2 distribusi frekuensi aktivitas fisik responden di Balai Kota Padang.

\begin{tabular}{ccc}
\hline $\begin{array}{c}\text { Aktifitas } \\
\text { Fisik }\end{array}$ & Frequensi & \% \\
\hline Ringan & 40 & 56,3 \\
\hline Sedang & 14 & 19,7 \\
\hline Berat & 17 & 23,9 \\
\hline Total & $\mathbf{7 1}$ & $\mathbf{1 0 0}$ \\
\hline Hasil penelitian didapatkan lebih dari
\end{tabular}

Hasil penelitian didapatkan lebih dari separoh 56,3\% karyawan usia produktif memiliki aktifitas fisik yang ringan. Hasil penelitian ini juga sejalan dengan penelitian (Abadini and Wuryaningsih, 2018) dengan judul determinan aktivitas fisik orang dewasa pekerja kantoran didapatkan lebih banyak masuk kedalam katergori aktivitas fisik yang ringan yaitu sebanyak 59\%.

Aktivitas fisik merupakan gerakan pada tubuh yang terjadi akibat dari kerja otot rangka sehingga dapat meningkatkan pengeluaran tenaga dan energi, aktivitas fisik juga merupakan kegiatan yang dilakukan dirumah, ditempat kerja, aktivitas selama diperjalanan dan juga aktivitas yang dilakukan untuk mengisi waktu luang. Aktivitas fisik dibagi menjadi 3 kategori yaitu aktivitas fisik ringan, sedang dan berat. Aktivitas fisik sangat penting dilakukan guna mencegah timbulnya masalah kesehatan (Amraeni, 2021). Aktivitas fisik yang dilakukan secara teratur dapat meningkatkan ketahan fisik serta menjaga tubuh dari permasalahan - permasalahan kesehatan lainya. Cara untuk menghindari tersebut yaitu dengan cara melakukan olah raga secara teratur setiap harinya. (Amraeni, 2021).

Hasil dari penyebaran kuesioner aktivitas fisik pada karyawan kantor Balai Kota Padang didapatkan kebiasaan aktivitas fisik yang dilakukan cenderung lebih ringan atau bahkan tidak ada sama sekali sehingga risiko terjadinya permasalahan kesehatan pada pekerja akan meningkat. Hal tersebut dipengaruhi oleh pekerjaan mereka yang menuntut untuk melakukan pekerjaan dibalik meja dan cenderung menetap. 


\section{c. Gambaran}

ketidaknyamanan/kesakitan pada tubuh karyawan usia produktif di Balai Kota Padang

Tabel 4.3 distribusi frekuensi responden berdasaran Nordic body map di Balai Kota Padang.

\begin{tabular}{ccl}
\hline $\begin{array}{c}\text { Nordic Body } \\
\text { Map }\end{array}$ & Frequency & $\%$ \\
\hline Rendah & 65 & 91,5 \\
\hline Tinggi & 6 & 8,5 \\
\hline Total & $\mathbf{7 1}$ & $\mathbf{1 0 0}$ \\
\hline
\end{tabular}

Hasil penelitian didapatkan lebih besar dari 91,5\% karyawan usia produktif mengalami kesakitan pada tubuh yang rendah.

Nordic Body Map ini merupakan pengukuran subyektif untuk mengukur rasa sakit otot para pekerja (Wilson R., 2005). Dalam hal ini pengukuran kuesioner melihat ergonomic pekerja yang paling sering digunakan untuk mengetahui ketidaknyaman pekerja karena sudah terstandarisasi dan tersusun rapih. (Wijaya, 2019).

Penilaian kuesioner Nordic Body Map ini sering digunakan untuk mengukur rasa tidak nyaman atau ketegangan otot pada pekerja berat, seperti buruh, pekerja kontruksi, produksi dan lain-lain. Pada penelitian ini peneliti mencoba menerapkan kuesioner ini kepada karyawan kantor, dan hasil nya didapatkan bahwasanya rasa sakit atau ketegangan otot pada karyawan kantor cukup rendah, hal ini disebabkan karena pekerjaan yang dibilang ringan ketimbang pekerja kontruksi lainya. Tapi pekerja kantoran tersebut juga bisa mengalami ketidaknyaman atau ketegangan otot seperti sakit pinggang, sakit bahu dan sendi-sendi lainya yang disebabkan oleh stuned atau kurang nya aktivitas gerak pada pekrja tersebut dan akan berdampak terhadap permasalahan kesehatan terutama penyakit tidak menular seperti, diabetes, hipertensi, stroke dan lain-lain.

\section{d. Kampanye Total Body Stretch}

Menindaklanjuti hasil penelitian dari gambaran yang telah didapatkan peneliti. penerapan kampanye pada karyawan Balai Kota Padang dilakukan dengan beberapa kegiatan yaitu dengan memasang spanduk dan Xbaner terkait Sedentary life style dan kurangnya aktivitas fisik serta bagaimana dan kapan karyawan harus melakukan total Body Stretch. Selain itu peneliti juga memberikan sosialisasi berupa promosi kesehatan kepada karyawan Balai Kota Padang terkait pengetahuan kesehatan dan peningkatan produktivitas kerja.

Pengetahuan terkait kesehatan sangat penting diketahui oleh pekerja sesuai dengan jenis pekerja masing-masing, agar permasalahan-permasalahan dan penyakit akibat kerja bisa diminimalisir dan dikendalikan.

\section{KESIMPULAN}

a. Berdasarkan hasil kesimpulan penelitian dengan menyebarkan kuesioner sedentary lifestyle didapatkan hasil yang sangat tinggi terkait kebiasaan kurang gerak pada karyawan usia produktif di kantor Balai Kota Padang.

b. Berdasarkan hasil kesimpulan peneliti terhadap aktivitas fisik bahwasanya separoh karyawan memiliki aktivitas fisik yang rendah. Hal tersebut di sebabkan oleh faktor lingkungan dan kurangnya pemaparan/ pengetahuan terkait aktivitas fisik.

c. Berdasarkan hasil penelitian didapatkan kesimpulan dari gambaran. Nordic body map pekerja masih terbilang rendah hal tersebut dikarenakan lingkungan fisik Balai Kota Padang masih menggunakan tangga manual dengan gedung empat lantai sehingga masih terjadinya gerakan yang massif pada pekerja dan juga usia yang rata-rata masih terbilang muda pada karyawan tersebut.

d. Hasil penelitian yang telah dilakukan oleh peneliti. Peneliti telah melakukan promosi dan kampanye terkait perilaku kurang gerak pada karyawan 
Balai Kota Padang dengan perlakuan total body stretch.

\section{SARAN}

a. Bagi karyawan Kantor Balai Kota Padang : diharapkan meningkatkan pengetahun terkait aktivitas fisik serta mengimplementasikan kegiatan fisik baik di rumah maupun di kantor untuk mengurangi dampak permasalahan kesehatan yang mungkin terjadi dimasa akan datang.

b. Bagi Wali Kota Padang : diharapkan mempromosikan dan menerapkan program aktivitas fisik pada karyawan di Kantor Balai Kota Padang.

c. Bagi peneliti selanjutnya : diharapkan peneliti melanjutkan penelitian dengan melihat hubungan antara variabel dari gambaran yang telah didapatkan dan selanjutnya melakukan penelitian terkait penerapan aktivitas fisik terutama penerapan total body streatch dengan perlakuan pre dan post.

d. Bagi profesi keperawatan ; dapat menambah khasanah keilmuan serta memperdalam ilmu khususnya terkait keperawatan kesehatan kerja.

\section{UCAPAN TERIMA KASIH}

Terima kasih peneliti ucapkan kepada Kementrian Pendidikan Kebudayaan, Riset dan Teknologi yang telah mendanai penelitian ini. Terima kasih juga kepada LPPM serta anggota yang telah mensupport dan memberikan pengarahan kepada peneliti sehingga penelitian ini dapat di selesaikan dengan sebaiknya. Terima kasih juga kepada anggota peneliti, Ibu Ns. Cindy Cleodora. M.kep.,Sp. Kep. J, yang telah berkolaborasi dengan baik sehingga penelitian ini selesai dengan baik. Tidak lupa juga ucapan terima kasih kepada teman-teman team yang telah membantu sehingga penelitian ini berjalan dengan baik.

\section{REFERENSI}

Abadini, D. and Wuryaningsih, C. E. (2018) 'Determinan Aktivitas Fisik Orang Dewasa Pekerja Kantoran di Jakarta Tahun 2018', Jurnal Promosi Kesehatan Indonesia, 14(1), p. $15 . \quad$ doi: 10.14710/jpki.14.1.15-28.

Amalina, D. N. (2020a) 'Perancangan Kampanye Sosial Tentang Pola Hidup Sedentary Melalui Video Animasi Di Media Sosial'. Available at: http://elibrary.unikom.ac.id (Accessed: 1 November 2021).

Amalina, D. N. (2020b) 'Perancangan Kampanye Sosial Tentang Pola Hidup Sedentary Melalui Video Animasi Di Media Sosial'. Available at: http://elibrary.unikom.ac.id (Accessed: 1 November 2021).

Amraeni, Y. (2021) Issu Kesehatan Masyarakat dalam SDG's - Yunita Amraeni - Google Buku. Available at:

https://www.google.co.id/books/edi tion/Issu_Kesehatan_Masyarakat_d alam_SDG_s/Ud5DEAAAQBAJ?h $\mathrm{l}=\mathrm{en} \& \mathrm{gbpv}=1 \& \mathrm{dq}=\mathrm{p} 2 \mathrm{ptm}+2017 \& \mathrm{p}$ $\mathrm{g}=\mathrm{PA} 209 \&$ printsec $=$ frontcover (Accessed: 1 November 2021).

Anderson, E. (2018) Community as partner: Theory and practice in nursing, 8th edition, Community as Partner: Theory and Practice in Nursing, 8th Edition. Wolters Kluwer Health/Lippincott Williams $\&$ Wilkins.

Anderson, E. T. and McFarlane, J. M. (2011) 'Community as partner: theory and practice in nursing', $\mathrm{p}$. 402. Available at: https://books.google.com/books/ab out/Community_as_Partner.html?id =ZJoDm8mg8YIC (Accessed: 1 November 2021). UNDANG REPUBLIK INDONESIA 
NOMOR 36 TAHUN 2009

TENTANG KESEHATAN (no date).

Available

at:

http://arifrohmansocialworker.blogs

pot.com/2011/02/undang-undang-

republik-indonesia-

nomor_8037.html (Accessed: 1

November 2021).

Guzik, A. (2013) Essentials for Occupational Health Nursing, Essentials for Occupational Health Nursing. doi: 10.1002/9781118783252.

Halajur, U. (2019) PROMOSI KESEHATAN DI TEMPAT KERJA Google Books, Wineka Media. Available at: https://www.google.co.id/books/edi tion/PROMOSI_KESEHATAN_DI _TEMPAT_KERJA/u4KGDwAAQ BAJ?hl=id \&gbpv $=1 \& d q=$ pengertia $\mathrm{n}+$ alat+pelindung+diri\&pg $=$ PT99\& printsec $=$ frontcover.

Mandriyarini, R. (2016) Sedentary Lifestyle Sebagai Faktor Risiko Kejadian Obesitas Pada Remaja Stunted Usia 14-18 Tahun Di Kota Semarang. Available at: http://eprints.undip.ac.id/62140/1/9 13_Retno_Mandriyarini.pdf.

Oakley, K. (2008) Occupational Health Nursing - NHS Careers. Edited by K. Oakley. John wiley \& Sons Ltd. Available at: http://www.nhscareers.nhs.uk/explo re-by-career/nursing/careers-innursing/occupational-healthnursing/ (Accessed: 1 November 2021).

Thyfault, J. P. et al. (2015) 'Physiology of Sedentary Behavior and Its Relationship to Health Outcomes HHS Public Access', Med Sci Sports Exerc, 47(6), pp. 1301-1305. doi: 10.1249/MSS.0000000000000518.

WHO (2012) 'Global Physical Activity Questionnaire (GPAQ) Analysis Guide', Geneva: World Health Organization, pp. 1-22. Available at: http://scholar.google.com/scholar?h $\mathrm{l}=$ en\&btnG=Search\&q=intitle:Glob al+Physical+Activity+Questionnair e+(GPAQ)+Analysis+Guide\#1 .

Wijaya, K. (2019) 'Identifikasi Risiko Ergonomi dengan Metode Nordic Body Map Terhadap Pekerja Konveksi Sablon Baju', Seminar dan Konferensi Nasional IDEC, 1, pp. 1-9. Available at: https://idec.ft.uns.ac.id/wpcontent/uploads/2019/05/ID075.pdf

Wilson R., J. (2005) Evaluation of Human Work, 3rd Edition - Google Books. Available at: https://books.google.co.id/books?hl $=$ en $\& 1 \mathrm{r}=\& \mathrm{id}=\mathrm{dSmKYLp} 82 \mathrm{~b} 4 \mathrm{C} \&$ oi =fnd $\& p g=P R 9 \& d q=W i l s o n+\% 26+$ corlett\&ots $=$ JIXmvLVtv\&sig=xzyb_5pfDoAi7IUET0 mhjhQ8NDk\&redir_esc $=y \# \mathrm{v}=$ onep age \&q=Wilson $\% 26$ corlett $\& \mathrm{f}=$ false (Accessed: 1 November 2021). 